\title{
Practical Study on Project Teaching Methods in College Practical Writing Teaching
}

\author{
Zhang Hongying \\ Chongqing Water Resources and Electric Engineering College, Yongchuan, Chongqing, P.R.China ${ }^{2}$ Department of Intelligent \\ Zhanghyprof@foxmail.com
}

\begin{abstract}
Project teaching method is able to change traditional teaching manner, and is crucial for raising teaching quality in writing classes, as well as students' practical writing. In this article, the writer summarizes practices in teaching, and discusses about the application of project teaching method in college practical writing teaching.
\end{abstract}

Index Terms - practical writing, project teaching method, practical study

\section{Introduction}

The purpose of college practical writing teaching is to raise students' practical writing skills, equip students with professional abilities and competitiveness in work, and lie the foundation of their future career as well as sustainable development of professional abilities. With the rapid development of college education, traditional teaching manners are no longer suitable to reach the teaching goals of college practical writing courses, so it is imperative to bring changes into practice. The department of college where the author works brings project teaching method into practical writing courses, and has done experiments and study in practice.

\section{The importance of project teaching method on college practical writing courses}

\subsection{The status quo of college practical writing teaching}

Teaching materials are too theoretical, and the contents are impractical. At present, most text books of practical writing inherit traditional teaching idea, in which system theoretical systematic and integrity are emphasized on, and practice as well as specific targets are ignored. Meanwhile, those books contain massive texts, large amount of information, and old examples, which makes them far from reality and students profession. This kind of textbooks neither facilitates teaching, nor are they suitable for the reality of college education.

Teaching mode is too simple to reach satisfying teaching results. Traditionally, the teaching of practical writing is carried out this way: the teacher introduces writing knowledge, analyze examples, and then students practice their writing, and finally the teacher would give comments. This kind of teachercentered pour-in method affects teaching qualities negatively on a large scale. In the entire process, students are in a passive position, and in lack of participation, which can't raise their interests in study, so that unsatisfying teaching and learning results can be predicted.

\subsection{Project teaching method is an ideal way to change the status quo of current practical writing teaching}

Project teaching method is a kind of teaching method, in which the teachers design projects according to teaching goals and requirements, and transform projects in teaching into tasks; students will fulfil those tasks under teachers' instruction, so as to master knowledge, and reach the study goal.

The most prominent characteristic in project teaching method is that "project is the main string, teachers are instructors, and students are the center". The entire teaching procedures are carried out from the project, and study process and learning process are combined organically. Through this teaching method, students must think, learn and practice by themselves to finish the tasks, so that traditional "teachers talk and students listen" way of teaching is changed, and in the new teaching mode, students would participate, coordinate and innovate. Accordingly, project teaching method is useful to raise students' interest, inspire their initiative, and raise their abilities in solving real problems, and ultimately, this will raise the teaching efficiency, and better realize the goal of college education.

\section{The application of project teaching method in college practical writing teaching}

\subsection{Design applicable practice-centered text books.}

Given the specialty of college education and the requirement of project teaching method, college practical writing courses should be seen as practical teaching, i.e. the application of knowledge should be emphasized, and the depth as well as abundance of theory should be properly reduced. Hence, designing text books for college practical writing becomes rather crucial and imperative. The author summarizing years of experiences of work in college practical writing teaching, published the book Tutorial for College Practical Writing Project Practice, which embodies utility, specialty and practice. The book put emphasis on project and tasks, and consists of ten projects, i.e. Daily Affairs, Social Protocols, Job Interview, Administration and Official Business, Meeting, Business Negotiation, Marketing Plan, Science Study, Lawsuit and Information Publication. Each project consists of several tasks, and in total the book contains 47 kinds of practical writing. Meanwhile, massive practical examples covering broad contents and large range are selected, in which teachers can choose according to course requirement. During designing the book, we tried to combine theoretical 
knowledge and practical skills in a certain project, and link it with practical tasks in industry and enterprise, so as to raise students' skills on practical writing and comprehensive qualities.

\subsection{Basic phases of project teaching method in teaching practice.}

Make the project clear according to the target. The goal of college practical writing teaching is not only to equip the students with good skills in writing, but also equip them with proper professional abilities. Hence, at the very start of project teaching, the teacher should introduce the contents of project and specific requirement according to goals of each unit, so that the students could have a basic understanding of the projects, clearly understand what professional abilities they are to master after studying and training in the project, and prepare for the planning and implementation of the project. For example, when studying the project Meeting, the teacher should make the students understand that the goal is to know the files needed in a meeting, master how to write relative articles, be able to write for meetings of each kind, and finish the tasks by setting a meeting.

Create situations and raise tasks. In order to instruct students to finish the tasks, the teachers should use multimedia and other teaching equipment to create a special working situation. This situation should be one that's linked with what the students are currently studying and close to real life. This kind of working condition can inspire students' enthusiasm and lead their interests to the special tasks that the teacher preset. Through fulfilling the tasks, the students combine theoretical study with solving practical problems. Here, in the project Meeting, the teachers gets to know that the Youth League Committee is about to hold a committee member meeting, and then shows how it was carried out last time. Then students combine the reality, raise five tasks as follows: writing a notice before the meeting, writing an opening talk when the meeting opens, writing records and brief reports during the meeting, writing a close talk when the meeting closes, and writing a report when the meeting ends.

Divide into groups and make plans. To ensure the projects are carried out smoothly, the teacher should divide students into groups before the implementing the projects. The groups should be made properly. The students could make groups according to their wishes, or the teachers could do it according students study and characters. Groups can help students help each other, coordinate with each other, and work together to fulfil tasks. The groups are led by group leaders under the teacher's instruction, and they will analyze and discuss about the tasks, and make specific text plans on how the tasks will be fulfilled. The teacher should read all the plans and notice problems, so as to ensure each group works according to the entire teaching plan. For example, in the project Meeting, a class of 50 students can be divided into five groups, and fulfill different tasks as follows: group I writs the notice, group II writes the opening talk, group III writes the meeting record and brief report, group IV writes the closing talk, and group $\mathrm{V}$ writes the report afterwards. According to the links among each task, the teacher should remind the groups to communicate and coordinate with each other so that the entire project could be complete.

Study together and finish the tasks. According to the plan and grouping, members of each group start to study. In certain study and work procedures, the group leaders should organize group members to study theoretical knowledge of each kind of writing, discuss the examples, and accumulate writing knowledge. Then they should refer to and collect relative data to know the importance and difficulty of the writing, make an outline, and form a draft. Finally, make modifications and finish the tasks. During the process, the teacher should take care of each group and participate in their study activities, know how the project is carried out, and answer students' questions on time. For groups that work slowly and those who find it difficult to finish the tasks, the teacher should render more help, and properly ensure the teaching goal can be fulfilled.

Share the results, and communicate. When each group has finished the tasks, they should make the result of their study into slideshows (including pictures, texts and videos), and each group should have a representative to demonstrate the study result, and then the students communicate about their study results. It could be carried out this way: the representatives make judgments on their own work, and then other groups discuss and judge, specify the advantage and disadvantage, and give opinions on modification. When groups have had sufficient communications, the teacher should give a summary, and give marks to each group according to preset standards. Finally, the teacher and students select the best group and best work.

\section{What we learn from project teaching method in college practical writing teaching}

\subsection{Project teaching method requires teachers to update teaching ideas, and make an effort to raise skills in practice and teaching study}

Project teaching method is actually a kind of inspiration teaching. Unlike traditional teaching method, the teachers must update teaching ideas, and switch their role. During teaching, teachers should change their role as a "teacher", switch from a main character to an assistant character, from the preacher of knowledge to guidance and leader in teaching activities. In the very beginning, the teachers should perfect their own knowledge structure according to the requirement of teaching revolution, and they should raise practical skills, and do more practice to make themselves the pen of their work. Only when they have strong abilities and plentiful experience in writing, can they better instruct their students in practical writing. Then, start from course revolution, according to the character of professional requirement and students' status, comprehensive textbooks, special project tasks, effectively managed classes and proper judging standards should be set to raise teachers' research abilities. Only when the teachers have strong abilities in research and teaching, can they better 
analyze teaching theories and problems arising from teaching practice, summarize and form regular recognition, so as to better guide their teaching practice.

4.2 Project teaching method requires students to change their traditional study ideas and effectively participate in teaching activities, and become the main characters in study.

Project teaching is a process guided by practice, in which students form their own knowledge and technique. The entire process embodies the idea that students should be the center, and transform their role to the main character in study, becoming the prosecutor and explorer in project activities. Hence, the teachers should help students change their traditional study mindset and methods, become independent from the teachers, and be no longer the recipient of knowledge, but positively participate in study activities. Under the guidance of teachers, the students should establish their own study platform, and through searching data, designing working plan, studying the methods and doing self-judgment, they look for methods and technique in practical writing, so as to find problems and solve them. Meanwhile, they form a good study habit, and raise study abilities, and ultimately realize the goal of mastering practical writing that can be applied in real life and work.

\section{References}

[1] Dong Nongmei: Status Quo of College Practical Writing Course and its perspective. (Jilin Television College Press 2011)

[2] Lv Zhongbao: The Comparison between Project Teaching Method and Traditional Teaching Methods. (Science Information 2007)

[3] Zhang Congming, Analyze the Application of Project Teaching Method in Practical Writing Teaching through Examples. (Fujian Commerce College Press 2009) 